\title{
PENGARUH KADAR KORTISOL TERHADAP KECEMASAN IBU BERSALIN DALAM PENGATURAN LINGKUNGAN PERSALINAN
}

\author{
Lusi Lestari, Heni Heryani \\ STIKes Muhammadiyah Ciamis \\ lusilestari.1987@gmail.com
}

\begin{abstract}
Abstrak
Kecemasan ibu bersalin yang terjadi terus menerus dapat mempengaruhi sistem saraf simpatik dan pelepasan hormon penyebab stres. Hormon yang produksinya meningkat karena persalinan diantaranya adalah hormon kortisol. Kortisol mempunyai banyak peran dalam sistem metabolisme dalam tubuh. Pengalaman persalinan dipengaruhi oleh lingkungan dan tempat berlangsungnya persalinan. Lingkungan dapat memberikan efek yang besar terhadap terjadinya kecemasan ibu bersalin. Memperhatikan aspek lingkungan ruang persalinan termasuk pendekatan non farmakologis untuk mengatasi kecemasan. Penelitian ini bertujuan untuk mengetahui pengaruh hormon kortisol terhadap kecemasan ibu bersalin dalam pengaturan lingkungan persalinan. Penelitian ini menggunakan metode eksperimen semu pre post test with control group design dengan 60 ibu bersalin di Bidan Praktek Mandiri (BPM). Uji analisis statistiknya menggunakan Uji Mann-Whitney, Uji T Tidak Berpasangan dan Uji Regresi Ganda.

Hasil penelitian menunjukan terdapat perbedaan rerata skor kortisol post $(p=0,000)$ dan peningkatan kortisol $(\%)(\mathrm{p}=0,007)$ pada kelompok perlakuan dan kelompok kontrol. Terdapat perbedaan rerata skor kecemasan saat pengukuran kedua pada kelompok perlakuan dan kelompok kontrol ( $\mathrm{p}=0,007)$. Peningkatan kadar kortisol (\%) tidak memiliki korelasi yang bermakna dengan kecemasan ibu bersalin karena nilai $\mathrm{p} \geq 0,05$. Simpulan penelitian ini adalah tidak ada pengaruh kortisol terhadap kecemasan ibu bersalin dalam pengaturan lingkungan persalinan.
\end{abstract}

Kata kunci : Kortisol, Kecemasan ibu bersalin, Lingkungan persalinan.

\section{Pendahuluan}

Persalinan adalah rangkaian proses yang berakhir dengan pengeluaran hasil konsepsi oleh ibu. Selama persalinan ibu mengalami rangkaian kejadian yang dimulai dengan adanya kontraksi uterus, dilatasi serviks sampai dengan pengeluaran bayi serta plasenta dan berakhir ketika dimulainya proses ikatan antara ibu dan bayi.(Varney et al., 2007) 
JURNAL ILMU KESEHATAN BHAKTI HUSADA:

HEALTH SCIENCES JOURNAL, VOL. 11 NO. 01, JUNI 2020 DOI: $10.34305 / J I K B H . V 1111.156$
Ciptaan disebarluaskan di bawah

Lisensi Creative Commons Atribusi-

NonKomersial-BerbagiSerupa 4.0

Internasional
Seorang ibu yang akan bersalin untuk pertama kalinya biasanya memiliki ketakutan yang berupa kebingungan dan mengembangkan reaksi kecemasan terhadap cerita yang mengerikan. Kecemasan akan ketidaktahuan tentang persalinan pertama itu adalah sesuatu yang normal. Akan tetapi, kecemasan yang terjadi terus menerus dapat mempengaruhi sistem saraf simpatik dan pelepasan hormon penyebab stres yang dapat menyebabkan kelahiran prematur dan infeksi rahim.(Wulandari, 2006)

Hormon yang produksinya meningkat karena persalinan adalah adrenalin, noradrenalin, dan kortisol. Kadar katekolamin dan kortisol yang tinggi saat melahirkan berkorelasi dengan kecemasan saat nyeri ibu. Kenaikan adrenalin dan kortisol yang lebih besar dari pada non adrenalin membuktikan stress mental lebih tinggi daripada stress fisik(Alehagen et al., 2001)

Kortisol adalah hormon steroid dari golongan glukokortikoid yang diproduksi oleh sel di dalam zona fasikulata pada kelenjar adrenal sebagai respon terhadap stimulasi hormone ACTH yang disekresi hipofisis. Kortisol mempunyai banyak peran dalam sistem metabolisme dalam tubuh. Kortisol secara fisiologis efektif dalam perawatan tekanan darah dan aktivitas antiinflamasi dengan menghambat sel darah putih untuk bekerja pada respon inflamasi.(Jesica \& Friadi, 2019)

Tingkat stress ibu yang tinggi dapat menyebabkan CRH pada kehamilan. Hal ini akan mengakibatkan peningkatan dan pelepasan $\mathrm{CRH}, \mathrm{ACTH}$, kortisol, estrogen, progesterone, dan hormone lainnya. Semua proses ini menyebabkan terjadinya persalinan preterm(Jesica \& Friadi, 2019)

$$
\text { Banyak faktor yang }
$$

mempengaruhi pengalaman perempuan saat melahirkan. Pengalaman persalinan yang dialami oleh setiap perempuan dapat dipengaruhi oleh lingkungan dan tempat berlangsungnya persalinan. Akan tetapi, lingkungan fisik sebagai salah satu faktor penting masih cenderung diabaikan. Lingkungan dalam proses persalinan memberikan efek yang besar terhadap terjadinya ketakutan dan kecemasan yang dialami dengan adanya aktivitas yang dilakukan berulang-ulang dan kurangnya privasi yang dapat berkontribusi terhadap kehilangan kontrol perasaan. Peningkatan kecemasan menghadapi persalinan muncul karena hilangnya kontrol perasaan dan dapat mengganggu fisiologi proses persalinan normal.(Lowe, 2002)

Berbagai terapi diberikan untuk mengatasi gangguan kecemasan, terdapat dua pendekatan yaitu pendekatan farmakologis dan pendekatan non 
JURNAL ILMU KESEHATAN BHAKTI HUSADA:

HEALTH SCIENCES JOURNAL, VOL. 11 NO. 01, JUNI 2020 DOI: $10.34305 /$ JKBH.V11I1.156
Ciptaan disebarluaskan di bawah

Lisensi Creative Commons Atribusi-

NonKomersial-BerbagiSerupa 4.0

Internasional. farmakologis. Bagi ibu hamil, pengobatan untuk mengatasi kecemasan harus mempertimbangkan risiko kerusakan pada janin akibat dari pengobatan tersebut. Sehingga pendekatan non farmakologi harus dipertimbangkan karena mungkin lebih baik untuk terapi kecemasan(Bandelow et al., 2014)

Memperhatikan aspek lingkungan ruang persalinan merupakan salah satu upaya peningkatan kualitas pelayanan maternal. Hal tersebut termasuk pendekatan non farmakologis untuk mengatasi kecemasan karena sebuah lingkungan fisik memiliki pengaruh pada pemikiran, perasaan, serta perilaku manusia. Namun sayangnya lingkungan yang dibentuk oleh rumah bersalin yang sudah ada sekarang justru memberikan rasa takut, kecemasan, kebosanan, dan stres pada ibu bersalin(Jenkinson et al., 2014)

Salah satu upaya yang dapat dilakukan untuk membuat lingkungan persalinan menjadi nyaman adalah dengan memanfaatkan desain interior. Dalam desain interior, sebagai lingkungan binaan, terdapat beberapa stimulus yang akan mempengaruhi indera manusia. Dari beberapa teori psikologi ada beberapa alat indera dan semua alat indera tersebut dapat dijadikan stimulus yang dimunculkan dari sebuah objek desain interior, manusia berinteraksi, berkomunikasi dengan ruang.
Beberapa teori membuktikan bahwa dari berbagai macam stimulus yang ada, stimulus visual mempunyai kemampuan paling dominan dalam menciptakan sensasi.(Sari, 2003)

Berdasarkan permasalahan diatas maka peneliti tertarik untuk mengambil judul "Pengaruh Kortisol terhadap kecemasan ibu bersalin dalam pengaturan lingkungan persalinan”.

\section{Metode}

Penelitian ini menggunakan metode Quasi Eksperimen, dengan PrePost Test Control Group Design terhadap 60 ibu bersalin kala I fase laten. Penilaian kecemasan menggunakan lembar kuesioner Zung Self-Anxiety Rating Scale yang harus diisi oleh responden untuk menilai tingkat kecemasan ibu bersalin. Terdapat 20 pertanyaan, dimana setiap pertanyaan dinilai 1-4 (1: tidak pernah, 2: kadangkadang, 3: sebagian waktu, 4: hampir setiap waktu). Terdapat 15 pertanyaan kearah peningkatan kecemasan dan 5 pertanyaan ke arah penurunan kecemasan. Pengukuran dilakukan sebanyak dua kali pada saat tidak ada his yaitu pengukuran pertama dilakukan pada saat ibu datang ke Bidan Praktek Mandiri (BPM) dengan fase laten di ruang persalinan, pengukuran kedua dilakukan setelah 60 menit ibu berada di lingkungan persalinan karena dianggap ibu sudah 
JURNAL ILMU KESEHATAN BHAKTI HUSADA:

HEALTH SCIENCES JOURNAL, VOL. 11 NO. 01, JUNI 2020

DOI: $10.34305 /$ JKBH.V11I1.156
Ciptaan disebarluaskan di bawah

Lisensi Creative Commons Atribusi-

NonKomersial-BerbagiSerupa 4.0 Internasional.

statistik menggunakan Uji Mann-whitney, Uji T Tidak Berpasangan, Uji Regresi Ganda.

untuk pemeriksaan kortisol pada fase laten

dan 10 menit bayi setelah lahir. Uji analisis

\section{Hasil}

Tabel 1.1 Perbedaan kadar kortisol pada kelompok perlakuan dan kelompok kontrol

\begin{tabular}{|c|c|c|c|}
\hline \multirow{2}{*}{$\begin{array}{l}\text { Kortisol } \\
(\mu \mathrm{gr} / \mathrm{dl})\end{array}$} & \multicolumn{2}{|c|}{ Kelompok } & \multirow{2}{*}{ Nilai $p$} \\
\hline & Perlakuan $(n=30)$ & Kontrol $(n=30)$ & \\
\hline Pre & & & $0,988^{*}$ \\
\hline Rerata (SD) & $371,202(121,837)$ & $429,125(245,551)$ & \\
\hline Median & 361,211 & 334,185 & \\
\hline Rentang & $140,000-579,856$ & $160,050-895,831$ & \\
\hline Post & & & $0,000 * *$ \\
\hline Rerata (SD) & $546,129(167,036)$ & $760,194(263,846)$ & \\
\hline Median & 523,374 & 799,797 & \\
\hline Rentang & $277,980-936,215$ & $305,490-1259,888$ & \\
\hline Peningkatan kortisol (\%) & & & $0,007 *$ \\
\hline Rerata (SD) & $57,299(55,871)$ & $108,215(85,859)$ & \\
\hline Median & 34,882 & 79,089 & \\
\hline Rentang & $1,93-211,04$ & $5,46-347,42$ & \\
\hline
\end{tabular}

Keterangan : *) berdasarkan Uji Mann -Whitney

**) berdasarkan Uji t tidak berpasangan

Dari tabel tersebut terlihat nila $\mathrm{p}$ pada pengukuran kortisol pre adalah 0,988. Karena nilai $\mathrm{p} \geq 0,05$ maka diambil kesimpulan tidak terdapat perbedaan rerata skor kortisol pre pada kelompok perlakuan dan kelompok kontrol. Sedangkan pada pengukuran kortisol post didapatkan nilai $\mathrm{p}$ yaitu 0,000 dan \% peningkatan kortisol (\%) didapatkan nilai $\mathrm{p}$ yaitu 0,007 . Karena nilai $\mathrm{p}<0,05$ maka diambil kesimpulan terdapat perbedaan rerata skor kortisol post dan peningkatan kortisol (\%) pada kelompok perlakuan dan kelompok kontrol. 
JURNAL ILMU KESEHATAN BHAKTI HUSADA:

HEALTH SCIENCES JOURNAL, VOL. 11 NO. 01, JUNI 2020

DOI: $10.34305 /$ JKBH.V11ı1.156
Ciptaan disebarluaskan di bawah

Lisensi Creative Commons Atribusi-

NonKomersial-BerbagiSerupa 4.0

Internasiona

Tabel 1.2 Perbedaan skor kecemasan pada kelompok intervensi dan kelompok kontrol

\begin{tabular}{|c|c|c|c|c|}
\hline \multirow{2}{*}{ No } & \multirow{2}{*}{ Skor Kecemasan } & \multicolumn{2}{|c|}{ Kelompok } & \multirow{2}{*}{ Nilai $\mathbf{p}$} \\
\hline & & Intervensi $(\mathrm{n}=\mathbf{3 0})$ & Kontrol $(n=30)$ & \\
\hline \multirow[t]{4}{*}{1.} & Pertama & & & $0,194^{*}$ \\
\hline & Rerata (SD) & $41,47(3,47)$ & $42,70(3,80)$ & \\
\hline & Median & 41,50 & 42,00 & \\
\hline & Rentang & $35-49$ & $37-51$ & \\
\hline \multirow[t]{4}{*}{2.} & Kedua & & & $0,007^{*}$ \\
\hline & Rerata (SD) & $41,77(3,49)$ & $44,47(4,02)$ & \\
\hline & Median & 41,50 & 44,50 & \\
\hline & Rentang & $34-52$ & $38-55$ & \\
\hline \multirow[t]{4}{*}{3.} & $\begin{array}{l}\text { Penurunan skor } \\
\text { kecemasan } \\
\text { Rerata (SD) }\end{array}$ & & & $0,259 * *$ \\
\hline & Median & $-0,30(3,95)$ & $-1,77(3,80)$ & \\
\hline & Rentang & $-1,00$ & $-2,00$ & \\
\hline & & $-6-8$ & $-9-7$ & \\
\hline
\end{tabular}

Keterangan : *) berdasarkan Uji t tidak berpasangan

**) berdasarkan Uji Mann -Whitney

Dari tabel tersebut terlihat nila $\mathrm{p}$ pada pengukuran skor kecemasan pertama adalah 0,194 dan nilai $\mathrm{p}$ penurunan skor kecemasan adalah 0,259 . Karena nilai $p \geq$ 0,05 maka diambil kesimpulan tidak terdapat perbedaan rerata skor kecemasan pertama dan rerata penurunan skor kecemasan pada kelompok intervensi dan kelompok kontrol. Sedangkan pada pengukuran kedua didapatkan nilai $\mathrm{p}$ yaitu 0,007. Karena nilai $\mathrm{p}<0,05$ maka diambil kesimpulan terdapat perbedaan rerata skor kecemasan kedua pada kelompok intervensi dan kelompok kontrol. 
Tabel 1.3 Pengaruh kadar kortisol dan pengaturan lingkungan persalinan terhadap skor kecemasan ibu bersalin

\begin{tabular}{llccc}
\hline & \multicolumn{1}{c}{ Variabel } & Koefisien B & Koefisien korelasi & Nilai p \\
\hline $\begin{array}{l}\text { Model } \\
\text { awal }\end{array}$ & $\begin{array}{l}\text { Pengaturan lingkungan } \\
\text { persalinan }\end{array}$ & $-2,571$ & $-0,326$ & 0,016 \\
& Peningkatan kortisol (\%) & 0,003 & 0,048 & 0,715 \\
& Konstanta & 44,193 & & - \\
\hline $\begin{array}{l}\text { Model } \\
\text { akhir }\end{array}$ & Pengaturan lingkungan & $-2,700$ & $\left.-0,342^{*}\right)$ & 0,007 \\
& persalinan & & & - \\
& Konstanta & 44,467 & & \\
\hline
\end{tabular}

Keterangan : *) $\mathrm{r}^{2}=11,7 \%$.

Berdasarkan hasil analisis regresi linier ganda di atas tampak secara multivariabel peningkatan kadar kortisol (\%) tidak memiliki korelasi yang bermakna dengan kecemasan ibu bersalin karena nilai

\section{Diskusi}

\section{Perbedaan Kadar Kortisol pada kelompok perlakuan dan kelompok kontrol}

Terjadinya peningkatan kortisol (\%) pada kedua kelompok karena kadar kortisol memang meningkat selama kehamilan dan terus meningkat sampai proses persalinan. Dalam sebuah studi disebutkan kadar kortisol dalam saliva selama persalinan meningkat dari $27,8 \pm 2.2 \mathrm{nmol} / \mathrm{L}$ pada kala I persalinan menjadi $64,1 \pm 4.2 \mathrm{nmol} / \mathrm{L}$ segera setelah plasenta lahir, diikuti dengan penurunan menjadi $12,6 \pm 1,3 \mathrm{nmol} / \mathrm{L}$ dalam $\mathrm{p} \geq 0,05$. Hanya pengaturan lingkungan persalinan yang memiliki korelasi yang bermakna terhadap kecemasan ibu bersalin, dengan besarnya $r=-0,342$; nilai $p<0,05$.

17 jam berikutnya(An-Nafi, 2009; Lidayana et al., 2013)

Akan tetapi kortisol post dan peningkatan kortisol (\%) lebih rendah pada kelompok perlakuan, hal ini karena pada kelompok perlakuan menerima perlakuan berupa pengaturan lingkungan persalinan. Sebuah lingkungan fisik memiliki pengaruh pada pemikiran, perasaan serta perilaku manusia. Sebagai sebuah lingkungan binaan, ruang memiliki stimulus yang mampu direspon oleh indera manusia penglihatan, pendengaran, pengecap, penciuman dan sentuhan), yang secara psikologis berpotensi membentuk persepsi 
JURNAL ILMU KESEHATAN BHAKTI HUSADA:

HEALTH SCIENCES JOURNAL, VOL. 11 NO. 01, JUNI 2020 DOI: $10.34305 /$ JKBH.V11I1.156
Ciptaan disebarluaskan di bawah

Lisensi Creative Commons Atribusi-

NonKomersial-BerbagiSerupa 4.0 Internasional. yang berpengaruh terhadap emosi dan perilaku manusia.(Anggawisastra et al., 2006)

$$
\text { Lingkungan dalam proses }
$$
persalinan memiliki efek yang besar terhadap ketakutan dan kecemasan yang dialami ibu.(Putri et al., 2013) Persalinan merupakan peristiwa fisiologis yang menimbulkan respon stress. Stres yang berlebihan (distress) akan menyebabkan ketidakseimbangan hormon sehingga menyebabkan peningkatan hormon kortisol. Kadar hormon kortisol digunakan secara luas untuk mengukur stress psikofisiologis. Kadar kortisol ibu dipengaruhi oleh dua mekanisme fisiologis yakni umpan balik kortikosteroid feto-uteroplasenta dan umpan balik negatif respon stres HPA-axis, inilah yang mendasari pengukuran hormon kortisol sebagai biomarker stres pada manusia. Dan manipulasi dibenarkan melalui perlakuan untuk mengurangi stres psiko fisiologis selama persalinan dapat mengurangi peningkatan kadar kortisol(Lidayana et al., 2013; NCT Policy Briefing, 2011)

Perbedaan skor kecemasan pada kelompok perlakuan dan kelompok kontrol

Adanya perbedaan yang bermakna pada pengukuran kecemasan kedua karena dianggap ibu bersalin sudah beradaptasi dengan lingkungan persalinan. Lingkungan dalam proses persalinan memberikan efek yang besar terhadap terjadinya ketakutan dan kecemasan yang dialami dengan adanya rutinitas dan kurangnya privasi yang dapat berkontribusi terhadap kehilangan kontrol perasaan.(Wulandari, 2006) Faktor lingkungan berpengaruh terhadap proses persalinan. Pada wanita primipara, ruang bersalin yang penuh $(70 \%)$ dan kurangnya mobilitas serta ruang gerak bagi ibu bersalin (67\%) berkontribusi terhadap terciptanya lingkungan yang menegangkan bagi mereka(Putri et al., 2013)

Salah satu pengaturan lingkungan yang diberikan adalah penataan furniture untuk mendukung mobilisasi karena pembatasan terhadap mobilisasi dapat berkontribusi terhadap peningkatan stress dan ketegangan. Sebaliknya pemberian kebebasan kepada ibu untuk mobilitas di ruang persalinan dapat meningkatkan hormon endorfin sehingga mampu mengatur hormon yang berkaitan dengan stress yaitu adrenal dan kortisol(Dahlan, 2011; Putri et al., 2013)

Selain itu, pemberian stimulus visual berupa kesan dekat dengan alam juga akan menunjang psikologis ibu untuk lebih tenang sehingga dapat mengurangi stress dan cemas saat persalinan(Dahlan, 2011; 
JURNAL ILMU KESEHATAN BHAKTI HUSADA:

HEALTH SCIENCES JOURNAL, VOL. 11 NO. 01, JUNI 2020 DOI: 10.34305/JIKBH.V11I1.156
Kementerian Kesehatan RI, 2010)Sehingga, dengan adanya pengaturan lingkungan yang mampu mengurangi ketegangan bagi ibu bersalin tersebut dapat menyebabkan adanya perbedaan yang bermakna pada pengukuran kedua yaitu setelah pengaturan lingkungan persalinan pada kelompok perlakuan.

\section{Pengaruh kadar kortisol dan pengaturan lingkungan persalinan terhadap skor kecemasan ibu bersalin}

Berdasarkan hasil analisis regresi linier ganda di atas tampak secara multivariabel peningkatan kadar kortisol (\%) tidak memiliki korelasi yang bermakna dengan kecemasan ibu bersalin. Hanya pengaturan lingkungan persalinan yang memiliki korelasi yang bermakna terhadap kecemasan ibu bersalin sebesar $11,7 \%$ dan sisanya $88,3 \%$ ada faktor lain yang tidak diteliti.

Cemas dan stress yang berlebihan (distres) akan menyebabkan ketidakseimbangan hormon. Kecemasan dalam persalinan menyebabkan respon stress sehingga terjadi peningkatan hormon katekolamin dan kortisol(Kalia, 2013; Sarwono, 2012) Peralatan persalinan yang nampak oleh ibu dirasa asing dan dapat meningkatkan kecemasan. Sehingga dengan penyimpanan alat persalinan di lemari dengan tujuan meminimalisir dari pandangan ibu bersalin dapat menciptakan ketenangan dan mengurangi suasana klinis sehingga ibu tidak mengalami kecemasan.(Amperiana \& Purnamasari, 2013; Kheirkhah et al., 2014)

Selain itu penggunaan musik yang menenangkan sebagai salah satu aspek dalam pengaturan lingkungan persalinan mampu meredakan kecemasan ibu bersalin dan membantu mengeluarkan hormon endorfin yang mampu mengatur hormon yang berkaitan dengan stress yaitu adrenal dan kortisol. Jadi pengaturan lingkungan persalinan berkorelasi dengan kecemasan melalui efek ketenangan dari pengaturan lingkungan persalinan sehingga meningkatnya pengeluaran endorfin yang berkaitan dengan hormon stress yaitu adrenalin dan kortisol(Satari \& Wirakusumah, 2011)

Pengaturan lingkungan persalinan berpengaruh secara psikologis terhadap suasana hati dan emosi, menciptakan ketenangan, pengurangan konsentrasi ibu terhadap stimulus negatif sehingga ibu tidak mengalami kecemasan. (Applebaum et al., 2010; Kementerian Kesehatan RI, 2010; Merrell et al., 2011)

Pengaturan lingkungan persalinan berpengaruh secara psikologis melalui stimulus penciuman, dimana ada hubungan yang kuat antara emosi dan bau sehingga bau dapat merubah suasana hati yaitu 
JURNAL ILMU KESEHATAN BHAKTI HUSADA:

HEALTH SCIENCES JOURNAL, VOL. 11 NO. 01, JUNI 2020 DOI: $10.34305 / J I K B H . V 1111.156$
Ciptaan disebarluaskan di bawah

Lisensi Creative Commons Atribusi-

NonKomersial-BerbagiSerupa 4.0 Internasional. dengan aroma yang menyenangkan memiliki kapasitas untuk menurunkan kecemasan.(Kementerian Kesehatan RI, 2010)

Penggunaan warna yang tepat juga berpengaruh secara psikologis karena setiap warna memberikan pengaruh psikologis yang berbeda, dan warna juga telah diakui memiliki efek terapi dengan penggunaan warna yang tepat dapat merangsang neokortek untuk memproduksi endorfin. Hasil penelitian menyatakan bahwa warna yang sesuai bagi ruang rawat inap adalah warna hijau pastel dan biru pastel karena akan memberikan kesan relaksasi(Anggawisastra et al., 2006)

Selain itu pengaturan lingkungan berpengaruh menciptakan ketenangan melalui stimulus visual berupa kesan dekat dengan alam. Kesan dekat dengan alam akan menunjang psikologis ibu untuk lebih tenang. Stimulus visual yang biopolik juga dapat membantu mengurangi stress dan cemas pada saat persalinan. (Dahlan, 2011)

Pengaturan lingkungan persalinan juga berpengaruh terhadap pengurangan konsentrasi ibu terhadap stimulus negatif sehingga ibu tidak mengalami kecemasan. Peralatan persalinan yang nampak oleh ibu dirasa asing dan dapat meningkatkan kecemasan. Sehingga dengan penyimpanan alat persalinan di lemari dengan meminimalisir dari pandangan ibu dapat menciptakan ketenangan dan mengurangi suasana klinis sehingga ibu tidak mengalami kecemasan(Kheirkhah et al., 2014)

\section{Kesimpulan}

Terdapat perbedaan skor kecemasan pada pengukuran kedua setelah ibu beradaptasi dengan lingkungan persalinan dan tidak terdapat korelasi peningkatan kadar kortisol terhadap kecemasan ibu bersalin dalam lingkungan persalinan.

\section{Referensi}

Alehagen, S., Wijma, K., \& Wijma, B. (2001). Fear during labor. Acta Obstetricia et Gynecologica Scandinavica, 80(4), 315.

Amperiana, S., \& Purnamasari, U. S. (2013). PENGARUH MUSIK KLASIK (MOZART) TERHADAP KEMAJUAN PERSALINAN KALA I FASE AKTIF PADA PRIMIPARA.

An-Nafi, A. F. (2009). Pengaruh kenyamanan lingkungan fisik ruang rawat inap kelas III terhadap kepuasan pasien di RSUI Kustati Surakarta.

Anggawisastra, R., Sutalaksana, I. Z., \& Tjakraatmadja, J. H. (2006). Teknik Perancangan Sistem Kerja. Bandung: ITB.

Applebaum, D., Fowler, S., Fiedler, N., 
JURNAL ILMU KESEHATAN BHAKTI HUSADA:

HEALTH SCIENCES JOURNAL, VOL. 11 NO. 01, JUNI 2020 DOI: $10.34305 /$ JIKBH.V11।1.156

Osinubi, O., \& Robson, M. (2010). The impact of environmental factors on nursing stress, job satisfaction, and turnover intention. The Journal of Nursing Administration, 40, 323.

Bandelow, B., Lichte, T., Rudolf, S., Wiltink, J., \& Beutel, E. M. (2014). The diagnosis of and treatment recommendations for anxiety disorders. Deutsches Ärzteblatt International, 111(27-28), 473.

Dahlan, M. S. (2011). Statistik untuk kedokteran dan kesehatan. Penerbit Salemba.

Jenkinson, B., Josey, N., \& Kruske, S. (2014). BirthSpace: An evidencebased guide to birth environment design.

Jesica, F., \& Friadi, A. (2019). HUBUNGAN KADAR KORTISOL DAN PROSTAGLANDIN MATERNAL DENGAN PERSALINAN PRETERM DAN ATERM. Jurnal Ilmu Keperawatan Dan Kebidanan, 10(1), 21-29.

Kalia, S. (2013). Colour and its effects in interior environment: a review.

Kementerian Kesehatan RI. (2010).

Peraturan Menteri Kesehatan Nomor 1464/MENKES/PER/X/2010 tentang

Izin dan Penyelenggaraan Praktik Bidan.

Kheirkhah, M., Pour, N. S. V., Nisani, L., \&
Ciptaan disebarluaskan di bawah

Lisensi Creative Commons AtribusiNonKomersial-BerbagiSerupa 4.0 Internasional

Haghani, H. (2014). Comparing the effects of aromatherapy with rose oils and warm foot bath on anxiety in the first stage of labor in nulliparous women. Iranian Red Crescent Medical Journal, 16(9).

Lidayana, V., Alhamdani, M. R., \& Pebriano, V. (2013). Konsep dan Aplikasi Healing Environment dalam Fasilitas Rumah Sakit. Jurnal Teknik Sipil Untan.

Lowe, N. K. (2002). The nature of labor pain. American Journal of Obstetrics and Gynecology, 186(5), S16-S24.

Merrell, P., Schkufza, E., Li, Z., Agrawala, M., \& Koltun, V. (2011). Interactive furniture layout using interior design guidelines. ACM Transactions on Graphics (TOG), 30(4), 1-10.

NCT Policy Briefing. (2011). Midwife-led units, community maternity units and birth centres Title.

Putri, D. H., Widihardjo, W., \& Wibisono, A. (2013). Relasi Penerapan Elemen Interior Healing Environment Pada Ruang Rawat Inap dalam Mereduksi Stress Psikis Pasien (Studi Kasus: RSUD. Kanjuruhan, Kabupaten Malang). Journal of Visual Art and Design, 5(2), 108-120.

Sari, S. M. (2003). Peran Warna pada Interior Rumah Sakit Berwawasan Healing Environment terhadap Proses 
JURNAL ILMU KESEHATAN BHAKTI HUSADA:

HEALTH SCIENCES JOURNAL, VOL. 11 NO. 01, JUNI 2020

DOI: $10.34305 / J I K B H . V 1111.156$

Penyembuhan Pasien. Dimensi

Interior, 1(2), 141-156.

Sarwono. (2012). Psikologi Lingkungan.

PT. Refika Aditama.

Satari, M. H., \& Wirakusumah, F. F. (2011). Konsistensi penelitian dalam bidang kesehatan. Bandung: Refika Aditama.

Varney, H., Kriebs, J. M., \& Gegor, C. L. (2007). Buku ajar asuhan kebidanan. Jakarta: Egc, 672-788.

Wulandari, P. Y. (2006). Efektivitas senam hamil sebagai pelayanan prenatal dalam menurunkan kecemasan menghadapi persalinan pertama. Fakultas Psikologi Universitas Airlangga. 